\title{
Lumen
}

Selected Proceedings from the Canadian Society for Eighteenth-Century Studies

\section{Treasures of the Imagination: Rethinking Pirate Booty in Pirate Narratives}

\section{Noel Chevalier}

Volume 37, 2018

URI : https://id.erudit.org/iderudit/1042221ar

DOI : https://doi.org/10.7202/1042221ar

Aller au sommaire du numéro

Éditeur(s)

Canadian Society for Eighteenth-Century Studies / Société canadienne d'étude du dix-huitième siècle

ISSN

1209-3696 (imprimé)

1927-8284 (numérique)

Découvrir la revue

Citer cet article

Chevalier, N. (2018). Treasures of the Imagination: Rethinking Pirate Booty in Pirate Narratives. Lumen, 37, 17-33. https://doi.org/10.7202/1042221ar d'utilisation que vous pouvez consulter en ligne. 


\title{
Treasures of the Imagination: Rethinking Pirate Booty in Pirate Narratives
}

\author{
Noel Chevalier \\ Luther College, University of Regina
}

In its issue for 29 July, 1721, the Weekly Journal; or, British Gazetteer featured an "Account of the Life, Behaviour, \&c." of Walter Kennedy, a pirate who had sailed with the notoriously successful pirate captain Bartholomew Roberts but who had established his own reputation by the time of his capture. ${ }^{1}$ Kennedy had been executed on 21 July, so the "Account" is really a final confession and expression of repentance that also attempts to explain Kennedy's attraction to piracy. Kennedy, we are told, had "served Her Majesty Queen Anne in the Wars against France, but being told what Lords the Pirates in America were, and that they had gotten several whole Islands under their own Command, he coveted to be one of those petty Princes." "The "Account," therefore, directly blames tales of wealthy pirates for corrupting the impressionable young seaman. Kennedy did achieve some success as a pirate, but, as he himself notes, his pirate career "had so ill prosper'd, that he should want a Coffin to cover his Carcase in."3 The message is clear: tales of wealthy pirates living like "petty Princes" are simply fanciful fictions, and rumours of pirate treasure should be ignored by any sensible individual.

1. Bartholomew Roberts (1682-1722) was the most successful pirate of the 1720 , taking over 400 ships. A full account of his defeat and the capture of his crew was published in A Full and Exact Account of the Tryal of all the Pyrates, Lately Taken by Capt. Ogle in 1723; this account was a major source for Charles Johnson's account of Roberts in General History of the Pyrates.

2. In Joel H. Baer, ed. British Piracy in the Golden Age, 1660-1730, (London: Pickering \& Chatto, 2007), 1.299.

3. In Baer, British Piracy, 1.300. 
The Kennedy account reveals that stories of pirate wealth seemed to have been common enough during the period of the most intense pirate activity. Another version of Kennedy's life, in The Lives of the Most Remarkable Criminals (1735), specifically mentions Kennedy's hearing tales "from the Time of Sir Henry Morgan's commanding the Bucchaneers in America, to Capt. Avery's more modern Exploits at Madagascar," although it provides no further details than that. ${ }^{4}$ What seems certain is that the stories featured these pirates both enjoying their wealth and assuming a certain degree of political power that had accrued to them from that wealth, but while pirates did sometimes grow rich from their plunder, their dreams of becoming rulers of anything remained as fantastic as Sancho Panza's. The most noteworthy pirate of the age, Henry Avery, whose capture of the Mogul flagship Ganj-i-Sawaj in 1695 had already passed into legend, was widely believed to have established a utopian pirate community on Madagascar, but no evidence that such a community ever existed has come to light. ${ }^{5}$ Whatever the tales might have said, few authentic pirate narratives-such as newspaper reports or official trial documentsrecord pirates living like "petty Princes." Certainly the closest that can be found to match such a reality were the buccaneers who, at the end of the seventeenth century, lived fully autonomous, albeit wretched, hand-to-mouth existences on uninhabited Caribbean islands: likely not the sort of thing Kennedy had in mind.

A century later, long after the pirates themselves had disappeared, stories of pirate wealth persisted in literary fiction. However, the treasures in these fictions are not ostentatiously displayed but buried; they have become obscure objects of desire that both invite and elude discovery. Neil Rennie, in Treasure Neverland (2014), suggests that the trope of buried treasure is almost entirely a creation of nineteenthcentury novelists, beginning in America, where much of this treasure was said to be buried. Tales of hidden pirate chests appealed to Washington Irving, eager to create "American rewritings of European

4. Lives of the Most Remarkable Criminals, who have been condemn'd and executed; for murder, highway, house-breakers, Street-Robberies, Coining, or other Offences; from the year 1720, to the present time. (London, John Osborn, 1735), 1.54.

5. Avery was the subject of a play, The Successful Pyrate, that enjoyed brief success at Drury Lane in 1712. A popular work of fiction based on Avery's legend, The King of Pirates (1720) has often been attributed to Daniel Defoe. 
folk-tales-moral fables, perhaps, demonstrating the consequences of neglecting the real world of impending progress in favour of illusory dreams of treasure buried and lost in the past." In associating piracy with the eighteenth-century past rather than the nineteenth-century present, with buried rather than evident treasure, the literary image of pirates became inextricably linked with a fantasy of potentially limitless wealth, since pirate booty in fiction almost always means gold, jewels, and precious stones: tangible commodities that could be converted into ready cash for the lucky finder's use.?

The buried-treasure trope in pirate fiction makes it difficult to locate the actual, historical pirates within their proper economic context or to see how pirate plunder-both real and fictional-encompasses larger concerns, such as colonialism and the rise of the British Empire. The main setting for these stories, the Caribbean, is reduced to a colourful, exotic backdrop for adventure stories and ceases to be what it clearly was during the early decades of the eighteenth century: an important locus of trade and a site of great political contest. Interestingly, vestiges of the colonial past do linger in the buriedtreasure stories, since the central tool of the treasure-seeker, the map, is also, as Edward Said reminds us, the central tool of the European coloniser, armed with what Said calls the "geographical notation, the theoretical mapping and charting of territory." 8 Buried treasure, therefore, gestures toward other buried treasures found in New World colonies: both the commodities derived directly from natural resources and the suitable conditions for establishing plantations in the very islands where these literary pirates roam. The pirate mythos, then, is not simply about wealth, or, as Peter Leeson suggests, even just economics,

6. Neil Rennie, Treasure Neverland: Real and Imagined Pirates (Oxford: Oxford University Press, 2014), 154 .

7. Buried treasure finds its way back to European fiction shortly after Irving's tales, most notably in Alexandre Dumas' Count of Monte Cristo (1843-44). Although the treasure Edmond Dantès discovers is the fortune of an aristocratic Italian family rather than of pirates, a whiff of piracy accompanies Dantès' finding the treasure and his transformation into the titular Count: he is brought to the island of Monte Cristo by smugglers, and he retains in his employ former petty criminals who would not have been out of place on a pirate ship. In effect, Dantès' assumption of the title of "Count of Monte Cristo"-the ruler of an otherwise uninhabited island-fulfils Walter Kennedy's fantasy of living as a "petty Prince."

8. Edward W. Said, Culture and Imperialism (New York: Vintage, 1994), 58. The italics are Said's. 
but with colonial economics, the Transatlantic exchange of goods.? What pirates steal in fiction, and what they stole in reality, both shed light on how eighteenth-century pirate narratives reflect larger concerns about colonial economic activity. While the nineteenth-century fictional pirate may, therefore, have something to say about the work of empire, it is important to remember that this same pirate figure is also fixed within a very narrow historical context-and the pirates of fiction are almost always historicised figures. ${ }^{10}$

If piracy is, by definition, inseparable from colonial commercial activity, then the imaginative shift from everyday commodities to the fantasy treasures of fiction represents a shift in perception both of pirates and of commerce itself. Piracy, we should recall, was primarily an economic problem in the 1720s: anxiety around piracy centred largely on pirates' ability to disrupt trade. As the author of the Discourse Relating to the Laws of Pirates and Piracy has it, "Piracy and Robbery at Sea is...so destructive of all Commerce between Nation and Nation, that all Sovereign Princes and States have thought it their Interest, and made it their Business, to suppress the same." of piracy suggest the same kind of anxiety: piracy is a threat to all commerce, important enough to involve "sovereign princes" in its suppression. Yet, at the same time, the notion of the pirate as a simple parasite, preying on legitimate commercial activity, offers too simplistic a model for the complex relationship between pirates and colonial settlements in the Caribbean. J.L. Anderson asserts that, during the 1716-26

9. Peter T. Leeson, The Invisible Hook: The Hidden Economics of Pirates. (Princeton: Princeton University Press, 2009).

10. Specifically, these pirates are locked in the period at the beginning of Empire, contemporary with the War of the Spanish Succession and the establishment of the South Sea Company. The action of Treasure Island, for example, is roughly determined to be some time after 1760 , and Long John Silver specifically claims to have sailed with Bartholomew Roberts in the 1720 s. John Sutherland has identified Silver's claims as one of the conundrums of Treasure Island, since Silver is said to be around fifty years old during the action of the novel, while the pirates Silver claims to have sailed with were active when Silver would either have been a very young child or even not yet born. Sutherland assumes the action of the novel to take place "in the late 1750 os or early 1760 s," and blames the odd chronology on Stevenson's having discovered Johnson's General History of the Pyrates only after he had started writing Treasure Island. See Robert Louis Stevenson, Treasure Island, ed. John Sutherland. (Peterborough: Broadview Press, 2012), 255-57.

11. A Discourse of the Laws Relating to Pirates and Piracies, and of the Marine Affairs of Great Britain. (London: W. Wilkins, 1726), 4. 
period, "piracy had become a business global in its reach, with plundered assets being no less mobile than the mariners who acquired them." 12 In order to emphasise the seriousness of piracy to Britain's colonial economic interests, the pirates themselves must be transformed into larger-than-life figures. Part of the fantastic iconography of pirate treasure has something to do with the need to see piracy as a different sort of phenomenon than what it actually was.

Contemporary historians of piracy, particularly Marcus Rediker and Mark Hanna, have demonstrated that pirates' relationship to their plunder was considerably more complicated than their fictional counterparts would have us believe. ${ }^{13}$ Pirate booty was meant to be used; it was shared fairly equally between captain and crew; most importantly, pirate "treasure" rarely took the form of precious metals or stones that could be buried for future use, although it was no less valuable to the pirates. Despite very little evidence that pirates ever did anything with their plunder other than sell it, spend it, or consume it, the image of the pirate as one who primarily buries treasure became one of the standard tropes of pirate fiction, displacing the image of the pirate as an active, if criminal, man of business. It might seem absurd to talk about "pirate businessmen"- the term has a kind of Pythonesque ring to it $^{14}$-and yet, there is every reason to see actual eighteenth-century piracy as something like a business, and every reason to think that pirates saw themselves as engaging in a form of commerce, a continuation of trade by other means. In actual pirate booty we encounter the products of everyday life that kept the wheels of commerce turning in

12. J.L. Anderson, "Piracy and World History: An Economic Perspective on World Predation.” (Journal of World History, 6.2 (Fall 1995), 175-99), 193.

13. See especially Marcus Rediker, Villains of all Nations (Boston: Beacon Press, 2004) and Mark Hanna, Pirate Nests and the Rise of the British Empire, 1570-1740 (Chapel Hill, NC: University of North Carolina Press, 2015). Margrette Lincoln, in British Pirates and Society 1680-1730 (Farnham: Ashgate Press, 2014), also deals with distribution of pirate wealth.

14. Perhaps because something very like that can be seen in "The Crimson Permanent Assurance," the sixteen-minute Terry Gilliam short that precedes Monty Python's The Meaning of Life (1983). In the film, an office of staid, elderly insurance clerks literally transform into pirates and seize control of the company from their oppressive corporate masters. Their London office building becomes a pirate ship, and is "launched upon the high seas of international finance." The connection with pirate films is underscored by extensive use of Erich Korngold's music for The Sea Hawk (1940). 
the eighteenth century. What pirates stole, and what they did with their plunder, can therefore be read against contemporary pirate narratives to redraw the portrait of piracy that later fictions have handed down to us and to understand more clearly how piracy was an integral part of everyday global commerce in the early-eighteenth century. We can, in fact, bring pirates in from the margins their fictional selves have been made to inhabit and reinstate them as part of a larger conversation about the uses of a global economy which raged within the intellectual landscape of the 1720 s. I would like, therefore, to examine pirate plunder in relation to the questions of why pirate narratives began to flourish in the 1720 s and how refitting these narratives within a context of everyday life can be useful for reading the more fanciful version of pirate treasure we encounter in more familiar fictions. The question at hand is, how did pirate "treasure" transform from everyday commodities to fantasy wealth? What purpose did such a transformation serve? And, perhaps most importantly, how do we read this transformation against an explicitly political agenda to eradicate the model of trade that pirate activity offered colonial settlements in the 1720 ?

\section{II}

While Rennie's account of nineteenth-century fiction is comprehensive and thoroughly mapped out, what remains to be explored is how contemporary accounts of pirate plunder helped to construct the mythology that these novelists exploited and developed. Eighteenthcentury readers would have encountered a remarkably different view of pirates than those of a century later, a view that saw pirates not as exotic hoarders but as very real participants in-and threats to-a nascent global economy that was becoming the commercial lifeblood of Britain. Pirate stories published during the period when pirates themselves were most active-especially the decade between 1716 and 1726 that was the most intense period of the so-called "Golden Age of Piracy" (roughly 1680-1730) - were far less fanciful than their nineteenth-century counterparts.

Pirate narratives that appeared during the Golden Age fell primarily into one of three genres: (1) newspaper accounts, which mostly record bare facts about ships plundered or pirates captured; (2) trial transcripts, which often provide eyewitness accounts of pirate activity 
and which also record precisely the amount of plunder taken; and (3) criminal biographies and "dying confession" pamphlets, which often focus on lurid details of a pirate's crimes, in part to drive home to the reader the moral repugnance of a life of piracy. Traces of all three types of sources can be found in the most significant and influential work on eighteenth-century piracy, Captain Charles Johnson's General History of the Pyrates (1724-28). ${ }^{15}$ Pirates appear occasionally in the fiction of the period-most notably in Defoe's novels-but even here, the pirate is hardly the exotic swashbuckler of later fiction, and his treasure is never buried. ${ }^{16}$

All of the above-mentioned texts stress that piracy is a profoundly real challenge to legitimate commerce that threatens the very political stability of Britain. Clearly, piracy was perceived during the period as being about more than just a few chests of coins or jewellery; in all of these narratives, the pirate's threat to all merchants-to all of commerce-is repeatedly emphasised. We do not often think of pirates as participating in everyday objects of exchange, or of pirates being especially interested in everyday commerce, but they certainly did and were. At the same time, the fact that they were interested in it means that we need to rethink our understanding of what pirates considered "valuable plunder." Measured by the anti-pirate literature which flourished in the 1720s, eighteenth-century piracy emerges as an important attempt to attain economic agency outside of the hegemony of British commercial structures (particularly_but not limited to-the East India Company and the South Sea Company). The parasitic nature of piracy also throws into question the nature of other, similar agents within a global economic system. How, for example, does the shifting

15. "Captain Charles Johnson" has long been understood to be a pseudonym, but a firm attribution of this seminal text has yet to be made. John Robert Moore confidently attributed the book to Daniel Defoe, but P.N. Furbank and W.R. Owens's The Canonisation of Daniel Defoe (New Haven: Yale University Press, 1988) cast serious doubt on Moore's claims. Arne Bialuschewski, in "Daniel Defoe, Nathaniel Mist, and the General History of the Pyrates" (Papers of the Bibliographic Society of America, 98.1 (2004), 21-38), suggests Nathaniel Mist as a likely author, but while it seems extremely likely that Mist had more to do with this volume than Defoe, evidence for Mist's sole authorship remains circumstantial.

16. Pirates appear-not surprisingly-in voyage and travel fiction in the 1720 , such as William Chetwood's Voyages and Escapes of Captain Richard Falconer (1720) and Penelope Aubin's Charlotta du Pont (1723). Most of this fiction seems to have been inspired by Defoe. 
nature of the legality of piracy-the blurred lines between legitimised privateers and illegitimate pirates-fit into this economic reality? Similarly-as pirates themselves were quick to point out-European states involved in colonial activity engaged in the same kind of rapacious plundering as pirate crews, with the exception that states enjoyed the legal protection of statehood. Piracy itself, as some narratives uneasily noted, often imitated the virtues found in successful businesses: ruthlessness, swift elimination of competition, and an eye for the main chance.

As the above-mentioned historians of piracy have been at some pains to point out, the pirate booty of literary fantasy also ignores many of the realities of pirate life, some of which can be reconstructed from surviving articles of piracy, to which every crew member was compelled to assent before being allowed a share of the plunder. ${ }^{17}$ For instance, both Bartholomew Roberts's and George Lowther's articles emphasise that any plunder taken belonged not to a single individual-certainly not the captain-but was shared equitably among all the crew. Captains and a few senior officers were allowed two shares, but the rest of the crew received one share each: this was in direct contrast to normal merchant shipping practice, which reserved shares of cargo only for ship owners and a few officers. Merchant crews were salaried men whose wages were dismally low when compared with the market value of the cargoes they carried. ${ }^{18}$ Furthermore, free spending of plunder was actually advantageous to pirates, who were welcomed and even sheltered as important contributors to the local economies. Finally-and, for our purposes, perhaps most significantly-few pirates were lucky enough to seize vast treasures of the sort that we find in pirate fiction. The very concept of a "pirate treasure" ignores the fact that pirating was a lengthy and often unrewarding activity. Pirates could go for days or weeks without spotting a ship

17. See Captain Charles Johnson, A General History of the Pyrates, first edition (London: Charles Rivington, 1724), 169-72 (Roberts) and 270 (Lowther). The same texts can be found (211-12 and 307-8, respectively) in Manuel Schonhorn's edition of the General History (New York: Dover Press, 1999), which he attributes to Defoe.

18. See Rediker, Between the Devil and the Deep Blue Sea, (Cambridge: Cambridge University Press, 1987), 121-24 and 304-5 for a detailed accounting of sailors' wages between 1700 and 1750 . Common seamen-the type most likely to be attracted to piracy-earned as little as 18 s. a month, and had no shares in the trading profits of the voyage. 
worth seizing; when seized, ships did not always yield any worthwhile commodities, or they provided little more than necessary provisions for ships forced to spend weeks or even months at sea. Pirates did, in fact, seize goods and valuable commodities from the ships they raided; in many cases, the ships themselves were the most valuable prize. But more often than not, what pirates stole consisted either of everyday merchant cargo, or necessary items for the pirates' own use: food, carpenter's tools and wood for repairing ships, and other such quotidian supplies.

It may be difficult at first to see how such mundane plunder could have far-reaching economic impact, perhaps even less than the precious commodities of pirate fiction. In fact, the role played by everyday objects in larger economic systems has only recently begun to be articulated in the study of Everyday International Political Economy (EIPE), the branch of International Political Economy (IPE) that seeks to reinstate how everyday life impinges on larger economic contexts. According to Leonard Seabrooke and John Hobson, conventional studies of IPE focus primarily on large-scale political and commercial institutions that regulate trade and therefore ignore the actions of everyday people in global economics. In contrast, Seabrooke and Hobson argue that "[o]ur everyday actions have important consequences for the constitution and transformation of the local, national, regional and global contexts." They note that "peripheral actors can challenge the legitimacy of how power is exercised." ${ }^{19}$ Everyday IPE (EIPE), then, "provides a focus that reveals how economic and political social actions by those who are not thought to be the dominant drivers of change have important consequences for the development and transformation of the world economy." ${ }^{20}$ While Seabrooke and Hobson are thinking primarily in terms of contemporary resistance movements to the hegemony of Amerocentric global commerce, such as the Fair Trade movement or the development of small-scale co-operatives, the principles of EIPE can be easily applied to early eighteenth-century pirates. In fact, Matthew Watson has located the roots of EIPE in the

19. Leonard Seabrooke and John Hobson. "The Case for an Everyday International Political Economy.” Working paper No. 26. Ed. Lars Bo Kasperson. (Fredriksburg, DK: International Center for Business and Politics, 2006): 3.

2o. Seabrooke and Hobson, "Case," 4. 
development of theories of the ethics of global capitalism that crystallises in the economics of Adam Smith.

Watson reminds us that, for Enlightenment thinkers, "[m]oral judgement was not something to be passed in a purely extrinsic manner after the economic activity had been undertaken" but rather "was fully endogenised as a crucial element of contemplating and then deciding upon the action itself." ${ }^{21}$ He notes, especially, that the Enlightenment concern with "manners" was tied up with a culture structured around possessions: these "new interpersonal relationships of politeness created forms of communicative action based on deference to possessions, which in turn caused the economy's productive potential to be increasingly harnessed to demands for possessiveness." 22 Watson locates much of the ethical discussion that underpins EIPE in Adam Smith's Theory of Moral Sentiments, but I think the roots of Smith's arguments can be traced back even further, specifically to the concerns over the growth of global commerce and colonialism that one finds in, for example, Bernard Mandeville's Fable of the Bees, Defoe's fiction, or even texts as late as John Gay's Polly. In particular, I think the anxiety over piracy in the 1720 , and the impulse to understand and contain piracy within the structure of narrative texts, such as Johnson's General History of the Pyrates, derive in part from piracy's own impulse to construct a culture that resisted, even subverted, the growing bourgeois culture whose moral code would be written three decades later by Adam Smith.

Viewing pirate narratives through the lens of EIPE, then, brings us close to the very concerned expressed in eighteenth-century pirate narratives. If we examine these narratives, we can immediately see that pirate booty often fell far short of the fantasy treasures of later fictions. For example, the trial account of John Quelch, tried with his crew in Boston on 13 June 1704, gives a detailed account of his plunder in nine separate acts of piracy committed between 15 November 1703 and 17 February 1704:

21. Matthew Watson, "The Eighteenth-Century Historiographic Tradition and Contemporary 'Everyday IPE'." Review of International Studies, 39.1, 2013, 1-23: 3.

22. Watson, "Historiographic Tradition," 5. 
1. 15 November: "A quantity of Fish and Salt, to the value of Three Pounds."

2. 18 November: "Five Chests of Brasil Sugar to the value of One Hundred and Fifty Pounds, Six Barrels of Molasses, to the value of Six Pounds."

3. 24 November: "Five Chests of Brasil Sugar to the value of One Hundred and Fifty Pounds, a quantity of Molasses, Rice and Farine, to the value of Ten Pounds."

4. 5 December: "a quantity of Earthen Ware, value Five Pounds, two Jarrs of Rhum, value Ten Shillings, and quantity of Linnen Cloth, value Ten Shillings."

5. 5 December: "some pieces of Cloth, value Five Shillings, Two Pieces of Silk, value Twenty Pounds, and sunk the said Boat, value of Thirty Pounds."

6. 9 December: "Fifty Pounds in Portuguise Coined Money, a Negro Boy, value Twenty Pounds, some Rice and Farine, value Five Shillings."

7. 20 December: "Five Chests of Brasil Sugar, value One Hundred and Fifty Pounds, and a small parcel of Portuguise Money, some Gold and Silver, value Fifty Pounds."

8. 15 January: "One Hundred Weight of Gold Dust, value Six Thousand Pounds, and Nine Hundred Pieces of Coined Gold, value Nine Hundred Pounds."

9. 17 February: "Twelve Barrels and a Pipe of Beef, value Ten Pounds, four great Guns, value Twenty Pounds, four Patteraro's, value Forty Shillings, Twelve small Arms, value Six Pounds, One Hundred Weight of Shot, value Three Pounds, two Barrels of Powder, value Twelve Pounds, a new Main-sail, Fore-sail, and Foretop-sail, value Forty Pounds, a Negro Boy, value Forty Pounds, and about Two Hundred Pieces of Eight, Spanish Money."23

If we leave aside Quelch's one capture of a ship yielding money$£ 6900$ in all-we are left with $£ 669$ worth of goods plundered, the most valuable of these being chests of Brazilian sugar, valued at $£_{25}$ each. Quelch's execution on 30 June 1704 became something of a cause célèbre, as he himself warned against settlers bringing in gold to a colony so hostile to his trade; his crewmember Erasmus Peterson lamented before he was hanged that “it is very hard for so many men's

23. See The Arraignment, Tryal, and Condemnation of Capt. John Quelch, And Others of his Company, (London: Ben Bragg, 1704), 2-4. 
lives to be taken away for a little Gold." ${ }^{24}$ Seven hundred pounds in goods is no small sum, but what I want to emphasise here is not so much the total value, but the actual goods and their value seized on specific raids. Each excursion over this three month period yielded primarily commodities-food and cloth being by far the most common. Quelch and his crew could have been hanged for any one of these acts of piracy, or even murdered by the crews of the ships they were plundering. Clearly, then, these everyday commodities were as "valuable," in the sense of the labour required to plunder them, as the one ship that yielded the prize of $£ 6900$.

Quelch, in his defence, argued that his seizure of Brazilian/ Portuguese goods was consistent with his former captain, Daniel Plowman's, license as a privateer. He claimed to have been unaware of a treaty signed between England and Portugal in May 1703, which effectively negated Plowman's privateering license. In any case, Quelch may already have overstepped his legal bounds when he assumed the right to plunder ships as a privateer when Plowman became indisposed. Although, of course, much was made at Quelch's trial of the gold dust he had plundered-a good deal of which found its way back to Boston-we should note that Quelch was also not above the considerable quantity of Brazilian sugar he had also stolen, in effect carrying out England's political enmity with Portugal by way of everyday commodities. Had Quelch carried out his attacks earlier in the year, he might have been lauded as a hero of commerce.

\section{III}

Turning from documents such as the Quelch trial record to narratives of the 1720 s, we can see how other types of narratives attempt to shape the multi-faceted phenomenon of eighteenth-century piracy into a coherent-and politically useful-image. While the idea of a pirate culture now seems fairly well-established, thanks mainly to the nineteenth-century writers mentioned earlier, in the 1720 s such a culture had yet to be defined, at least in print. Unlike the trial documents, however, the longer narratives tend not to dwell on the details of plun-

24. In Mark G. Hanna, Pirate Nests and the Rise of the British Empire, 1570-1740. (Chapel Hill, University of North Carolina Press, 2015), 332. 
der, preferring instead to record names of ships taken, or to focus on the violence associated with both robbery and capture. In some cases, however, details of pirate booty might serve as a commentary on a pirate's character. If we want an image of a pirate whose inventory of stolen goods is far from the treasures of pirate fiction, we need look no further than the short, yet memorable, career of John Gow. Gow is especially noteworthy in part because a pamphlet account of his career, An Account of the Conduct and Proceedings of the Late John Gow, alias Smith, appeared on 2 July $1725 .{ }^{25}$ According to the Conduct and Proceedings pamphlet, Gow and a small group of co-conspirators seized the George Gally from the parsimonious and unpleasant Captain Oliver Furneau in November, 1724. Gow was acclaimed as captain, and the ship, now renamed the Revenge, set out to make its fortune. However, Gow's first act of piracy, if the Conduct and Proceedings pamphlet is to be believed, is hardly the stuff of pirate legend:

The first Prize they took was an English Sloop, belonging to Pool, Thomas Wise, Commander, bound from Newfoundland with Fish, for Cadiz: This was a Prize of no Value to them, for they knew not what to do with the Fish; so they took out the Master, Mr. Wise, and his Men. Who were but Five in Number, with their Anchors, and Cables, and Sails, and what else they found worth taking out, and sunk the Vessel. ${ }^{26}$

Gow seems to have had a knack for chasing down fishing vessels: his next prize was a Glasgow ship filled with herring and salmon, which again the pirates robbed of useful items, such as guns, ammunition, sails, and cables, and sank whatever was left behind. Much of Conduct and Proceedings is structured to suggest that Gow was, in fact, a most incompetent pirate, perhaps to explain the utterly foolish gesture he makes of returning to his home in the Orkneys, which ultimately leads

25. This pamphlet was advertised as being in press in early June 1725 , a few days before the third edition of Johnson's General History - whose only change from the second edition is the chapter on Gow-was rushed into print on 10 June, the day before Gow's execution. John Robert Moore attributed Conduct and Proceedings to Defoe, partly to bolster his claim that Defoe also wrote the General History. However, the two accounts' disagreement over certain elements in Gow's narrative and the fact that Thomas Warner seems to have been directly competing with Conduct and Proceedings over Gow's story suggest at the very least that Defoe could not have written both accounts, if he had anything to do with either.

26. An Account of the Conduct and Proceedings of the Late John Gow, alias Smith. (London: John Applebee, 1725), 13. 
to his capture. Before this, however, Gow finds some measure of success in capturing a French ship that is laden with quite desirable booty, "the very thing they wanted," according to Conduct and Proceedings. ${ }^{27}$ This booty, however, consists not of precious metals and jewels, but of "Wine, Oyl, and Fruit."

Note that the author of Conduct and Proceedings directs the reader's attention not just to the goods seized but also to their presumed value to the pirates. Whereas official trial transcripts, such as John Quelch's, merely provides us with dry registers of plunder, the pamphlet narrative attempts to provide motive and reaction. We are explicitly told that the plunder of fish was of "no value," in part to set up a power struggle between Gow and his first mate that will come later. Gow's command is seemingly called into question after a series of "worthless" takes. What the narrative attempts, then, is a way of directing the reader and, as a result, a way of directing how we are to see piracy as a whole. The everyday goods that form the backbone of transatlantic trade are less attractive to readers; what matters more is the idea of the pirate as an enemy to all trade, and this idea is thus the first step in abstracting the pirate from the realities of everyday commerce.

The template for the kind of pirate narrative we find in Conduct and Proceedings had already been established in 1724 , with the publication of Johnson's General History of the Pyrates. General History did more to establish the broad outlines of a pirate culture than any other single text, but even in Johnson the idea of celebrating the actions of what were, after all, deadly criminals is fraught with its own moral complexities. More importantly, General History was by far the most important-and, in some cases, the only-source for pirate narratives. Some version of the General History remained in print well into the nineteenth century, ${ }^{28}$ and Stevenson used it as an historical source in Treasure Island. The impact of General History in shaping the literary pirate cannot be overstated.

27. Conduct and Proceedings, 19.

28. After the two-volume version of the Fourth Edition appeared in 1728, the General History was often reprinted with biographies of land criminals. Some chapters-particularly the chapters on Henry Avery and Blackbeard-were reprinted as separate pamphlets. An 1834 edition published in Hartford, CT, essentially reprints the Fourth Edition's Volume II as a standalone "History." 
Johnson vacillates between condemning piracy as among the worst of all crimes and suggesting that even "a Parcel of Robbers" could have legitimised themselves: "had they all united, and settled in some of those Islands, they might, by this Time, have been honoured with the Name of a Commonwealth, and no Power in those Parts of the World could have been able to dispute it with them." 29 A plagiarised, condensed version of Johnson's book was published by Edward Midwinter in 1725 , under the title of History and Lives of all the Most Notorious Pirates. Unlike Johnson's original book, which explicitly avoids imposing a didactic or moralistic purpose for the book, the anonymous editor/adapter of History and Lives quite explicitly states that "The Design of Publishing this Book...is to caution the unwary Mariner against the Temptation he may meet with at Sea, as also to shew the Merchant what Perils poor Sailors undergo to make them Rich and Great." 30

While Johnson does not condemn piracy as explicitly as the Midwinter version, many of the subjects Johnson features helped to establish the pirate as a bloodthirsty, misanthropic anti-hero. In the same way, pirate booty is transformed in these narratives, treated not just as everyday commodities but as part of a larger metanarrative about the importance of commerce and the sustainability of both Britain as a nation and the Caribbean as a British colony. If the pirate is an integral part of colonial commerce, Johnson suggests, then Britain may wish to reconsider its dependence on colonial trade. In the narrative of Edward Low and his crew, for example, we see how the figure of the pirate stands in relation to the goods they stole. We learn from General History that Low and his crew

in November 1722...got in with the Cape de Verd Islands, and cruising to the Eastward of them...took two Ships coming from Lisbon, one English and the other French, bound to St Michaels, the Commanders Names were Chandler and Roach: They plundered them of several Sorts of Goods, Provisions, and Stores, and let them go; but meeting with an English Pink bound to the same Place, with several Passengers on Board,

29. "Captain Charles Johnson," A General History of the Robberies and Murders of the Most Notorious Pyrates, first edition (London: Charles Rivington, 1724), A4 ${ }^{v}$. Hereafter designated as $1724 a$.

30. History and Lives of all the Most Notorious Pirates. (London: Edward Midwinter, $1725), \mathrm{A}_{3}{ }^{\mathrm{r}}$. 
who were willing to fight for what they had, they inhumanly murthered three or four of them, tho' they let the Ship proceed on their Voyage.

After the taking of these Ships, they went into one of the Islands, and took in fresh Water; when they came out again, they seized at Bonavista, a Ship call'd the Liverpool Merchant, Captain Goulding; they took from her a great Quantity of Provisions and dry Goods, 300 Gallons of Brandy, two Guns and Carriages, a Mast, a Yard, and Hawsers, and six of their Men; after which they would not suffer them to trade there, or at St Nicholas, with what they had left, but forced Captain Goulding to go to the Isle of May with his Ship. ${ }^{31}$

Low's taking of the ship is inextricably bound up with his "inhuman murther" of innocent sailors. General History, in fact, emphasises Low's sadism, whereas other accounts present him in a slightly different light. According to Philip Ashton, a Massachusetts fishing captain who was captured by Low in 1719, Low seemed especially eager not to dispose of able sailors, but forcefully-as in, at the end of pistolencouraged men to join his crew. ${ }^{32}$

George Lowther's plunder is even further removed from the treasure of pirate fantasy. Not only does Lowther gain his goods without a fight, he mimics the forms of trade itself when he seizes a French vessel:

After this, the Delivery proceeded to Hispaniola; near the West End of the Island she met with a French Sloop loaden with Wine and Brandy; aboard of this Vessel went Captain Massey, as a Merchant, and ask'd the Price of one Thing, and then another, bidding Money for the greatest Part of the Cargo; but after he had trifled a while, he whispered a Secret in the French Man's Ear, viz. That they must have it all without Money. Monsieur presently understood his Meaning, and unwillingly agreed to the Bargain. They took out of her thirty Casks of Brandy, five Hogsheads of Wine, several Pieces of Chintzes, and other valuable Goods, and about seventy pounds English, in Money; of which Lowther generously return'd five Pound back to the French Master, for his Civilities.33

31. Johnson, General History (1724a), 289-90. This passage does not appear in Schonhorn.

32. See Gregory N. Flemming, At the Point of a Cutlass: The Pirate Capture, Bold Escape, and Lonely Exile of Philp Ashton (Lebanon, NH: ForeEdge/University Press of New England, 2014) and John Barnard, Ashton's Memorial; or, An Authentick Account of the Strange Adventures and Signal Deliverances of Mr Philip Ashton (London, Richard Ford and Samuel Chandler, 1726) for Ashton's encounter with and observations on Edward Low.

33. Johnson, General History (1724a,) 271 [Schonhorn 308]. 
Note even the last gesture, a measure of good-will for such a co-operative victim.

Pirate treasure, imagined in terms of "elite" commodities rather than everyday possessions, reframes the parameters of discussion about the place of piracy within this nascent global economy. There is a kind of "Robin Hood" mentality about the pirate of fiction, in which the pirate acts as an agent against the rapacious, avaricious wealthy, presumably either recirculating that wealth in a spirit of freedom and enjoyment or, in a more twisted bit of social levelling, takes it out of circulation altogether by burying it, in theory leaving it available for anyone to discover. Pirate activity certainly focuses on "the bottom-up processes and the everyday actors which both effect change in the... global structural contexts," but in order to see these processes at work, we must see pirate activity for what it truly is - an attack on everyday commodities and everyday trade. ${ }^{34}$ Piracy certainly brings to the forefront the agency of the so-called "99 percent" in effecting social change; at the same time, we must be careful to avoid the view of pirates as proto-radicals or proto-libertarians, free agents acting on behalf of a larger social agenda. Pirates are liminal figures, both participating in global commerce and undermining it. Narratives such as we find in the General History seem acutely aware of this kind of contradiction, since the book acknowledges the potential "greatness" of pirate captains, while at the same time never letting the reader forget that pirates are, in fact, guilty of serious capital crimes. With a stronger connection between piracy and everyday economic activity, piracy emerges as a much more dynamic and more intrinsic part of our understanding of the ethics of commerce.

34. Seabrooke and Hobson, "Case" 15. 